\title{
6
}

\section{Unbounded nationalism: Florence 1867}

\begin{abstract}
W hen Florence hosted the sixth international statistical congress in the autumn of 1867, the city had been the capital of the newly united Italy for just three years. In 1864 the Italian government - pressured by the French - had decided to relocate the seat of government from Turin to Florence. In exchange, the French army would withdraw from Rome, a promise it reluctantly fulfilled, but not until 1870. In 1864 many suspected or hoped that 'Firenze Capitale' would be short-lived. If Rome were ever annexed, the Eternal City would undoubtedly become the country's permanent capital. Nevertheless, Florence spared no expense or effort to fashion its image as a true capital city.

The ink was barely dry on the national parliament's decision to relocate when the city government commissioned architect Giuseppe Poggi to design an ambitious expansion plan. The most radical undertaking of all was the demolition of the city walls and creation of a broad boulevard modelled on Baron Georges Haussmann's project in Paris. Several buildings were demolished in the old city centre and construction began on new residential neighbourhoods. The statisticians who made their way to Florence witnessed a massive wave of demolition, as they had in Paris twelve years earlier. An old world was vanishing before their eyes, and the new one was no more than a blueprint. But that was how statisticians saw the world: all at once volatile, threatening and challenging. Statistics was their blueprint.

Florence was eager to position itself as a city of culture and organised several national festivals. In 1861 - soon after unification - it hosted the first national exhibition. The Santa Croce church was gradually transformed into a pantheon of Italian heroes. In 1865 the city council organised a large-scale national festival to commemorate the six-hundredth anniversary of Dante Alighieri's birth, which would enhance the city's stature as the nation's capital. King Victor Emanuel II was there as a guest of honour and - in the presence of the majority
\end{abstract}


of parliamentarians and civil servants - officially took up residence in his new home. Ugo Pesci reported in his chronicle of the Firenze Capitale years that the king honoured the statistical congress two years later by inviting the conferees to a gala luncheon at Palazzo Pitti. ${ }^{1}$

In the spirit of the times, Pesci praised the work that Pietro Maestri, organiser of the Florentine congress, had done during the Risorgimento. Like many politicians and civil servants of the new state, Maestri had stood on the barricades for Italian unification. Born in Milan in 1816, he graduated with a degree in medicine from the University of Pavia and was active in the Lombardy democratic movement from a young age. He was a student of the jurist Gian Domenico Romagnosi and the political philosopher Carlo Cattaneo. He was a member of the Committee of Defence in Milan during the revolution of 1848 and later briefly served as a representative to Tuscany of the revolutionary government in Rome. After the Roman revolution was quelled, he fled to Piedmont and then to France. In Turin he published two statistics annuals (on 1852 and 1853) in which his liberal-nationalist agenda is clearly recognisable. ${ }^{2}$

In the foreword to the 1853 annual, Maestri equated statistics with patriotism. Statistical inquiry made it possible to 'determine precisely the true strength of the nation's capacities, and by studying economic unity to reinforce geographical and ethnographical unity and the political ideal. ${ }^{3}$ In 1862 he became the first director of the statistics division of the young state's Ministry of Agriculture, Industry and Trade. His appointment, which was supported by influential friends like Cesare Correnti, was the pinnacle of a life devoted to statistics in the service of a united Italy.

The congress in Florence brought Maestri international fame. The congress venue stirred the imagination of the conferees. It was held in the Uffizi, in the section assigned to the Italian senate two years before. The plenary meetings were held in the impressive Teatro Mediceo, designed by Bernardo Buontalenti and inaugurated in 1586 . The space had not been used as a theatre since the end of the Medici family's rule in Florence. It had housed the Tuscan criminal court for a long time and was taken over by the senate in 1865 following unification. Today, only the entrance on the first floor of the Uffizi remains visible.

In addition to the official congress bureau, the organisers set up a committee of distinguished citizens to ensure their guests were received appropriately. The conferees were given a pass allowing them access to museums, libraries, benevolent societies, prisons and printing houses (all regarded as manifestations of modern civic life, for better or worse). And art and culture were available in abundance. The committee offered a programme of special visits and walking tours, including an excursion to a horticulture exhibition near Porta San Gallo, a walk in the Parco della Cascine, a supper at the prime minister's home, an evening visit to the national museum, a dinner at the Pagiano theatre and a concert at La Pergola. Florence made the most of every opportunity to affirm its status as a city of culture. 
The Florentine congress was an opportunity for the liberal elite of the new Italian nation to present themselves to the rest of Europe, and to one another. They saw Italian unification as more than the sum of its parts. This unique arithmetic of nationalism did not escape the attention of the Italian statisticians. They proudly presented the series of statistics publications that their newly unified state had managed to produce in a short time, and harked back to the history of statistics in different regions of the Italian peninsula. There was but one outcome to be expected from the study of those historical accounts: a national statistics that would lay the foundation for liberal reform policies.

In the introduction to the overview of statistical productivity since unification, Pietro Maestri looked back at reports written by Venetian ambassadors, Tuscan diplomats and papal nuncios of the early modern period. He gleaned from Niccolò Machiavelli's work, for example, that it was an old Italian tradition for statesmen to base political action on statistical information. Of course Maestri also alluded to more recent heroes of Italian statistics. Like every statistician of his day, he paid homage to the ideas of Melchiorre Gioia (1767-1829) and Gian Domenico Romagnosi (1761-1835), who were invariably cited when it was necessary to underscore the existence of a national statistics tradition. This is perhaps remarkable since Gioia and Romagnosi had died decades before unification and never positioned themselves as dyed-in-the-wool nationalists, but at the same time unsurprising. Nationalism has a tendency to avail itself of mythical traditions.

Gioia earned renown as an eminent statistician back in the time of Napoleonic Italy. In 1806 he became director of the statistical commission, and later the statistical bureau, of the Regno d'Italia in Milan. In 1808 he published his detailed 'Statistical tables, or standards for the description, calculation and classification of all elements of private and public administration'. To him, statistics was no more and no less than an administrative science, an instrument used by government to regulate society. In the spirit of the English moral philosopher Jeremy Bentham, whose work he knew well, he stressed the 'true value' of statistics, 'which serves the people, every occupation group, the government and future generations. ${ }^{4}$ After the end of French rule, he continued his work on statistics, though not directly in the service of the government (the Austrian regime in Northern Italy did not approve of Gioia's wish to make statistical data public), but as an independent scholar and journalist.

Gioia publishedhisprincipalwork, Filosofiadellastatistica, in 1826. Hedefined statistics as an 'economic description of the nations' containing all elements of a country that 'can be of benefit to everyone or a majority of the people, and to the government.. This covered a profusion of subjects: topography, population, agricultural and industrial production, trade, taxation, government, institutions and national customs. Every area could be broken down into countless subcategories. Topography included everything that we associate with geography and meteorology. Gioia believed that wind, for example, was a major factor affecting the economic structure of a country: 'The Dutchman builds a windmill, mounts a rotation and compression mechanism onto it, orders it to drain a swamp and 
the mill obeys. Behold, a statistical fact that does not cease to be true from one moment to the next.' ${ }^{6}$ Intellectual, economic and moral traditions had at least as much continuous influence on the nations and were therefore also statistical facts. Gioia gave as an example the hospitality consistently displayed by all the peoples of Northern Europe, a circumstance from which both the political economist and the traveller benefited. Though the title suggests otherwise, Gioia's Filosofia della statistica is not an in-depth analytical work but rather a practical springboard to a full-scale descriptive statistics.

Romagnosi took a more theoretical perspective. He approached statistics from his experience as a jurist, so his ideas about statistics were, in the final analysis, based on his legal background. He deduced the function of statistics from the notion that everything should be subject to an institutional, legal order. Without order, there could be no state and no society. The 'statistica civile' indicated the degree of civilisation, or 'incivilimento', of a people. This went beyond a basic study of economic factors, which is what his influential contemporary, the Frenchman Jean-Baptiste Say, was mainly interested in. For Romagnosi, political and moral progress, as well as economic development, were the marks of true civilisation.

What made Gioia and Romagnosi so interesting to the latter-day architects of the unified Italian state was that an argument for a specific Italian statistics could be gleaned from their work. ${ }^{7}$ Where Gioia and Romagnosi saw in statistics the essence or at least a major component of a new kind of political science, later generations interpreted their ideas as a call for a science of a new political entity. Maestri and his peers considered themselves followers of Gioia and Romagnosi. They believed they could bring to fruition what their mentors could only have dreamt of. From that perspective, it was possible to allow the geographical, ethnic and economic diversity of the Italian peninsula to dissolve into a national discourse. The Italian statisticians were arguing precisely the opposite of what Czoernig had tried to show in 1858, from the Austrian perspective: namely that nationalist aspirations in Italy were futile in the face of ethnic differences in the region stretching from the Alps to Sicily (see Chapter 3). This shows just how malleable statistics was in the nineteenth century. In a demonstration of his conciliatory disposition (and political sea change in Austria in 1867), Czoernig addressed the Florence congress in Italian only a year after the war between Italy and Austria, and spoke emphatically about the close relationship between administrative statistics and parliament. ${ }^{8}$

Prior to unification, every state on the Italian peninsula, not just Lombardy, had kept statistics and had its own heroes. In Piedmont, the Napoleonic tradition of 'prefectural' statistics had survived, thanks in part to the fact that it contained elements of the seventeenth and eighteenth-century Piedmontese state. Local officials saw it as their duty to redact the statistics collated by provinces and other entities of public administration in order to support the administrative monarchy.' The Venetian geographer Adriano Balbi wrote several 'political-statistical' works about Europe and the world which were used by others to compare the degree of civilisation of various countries and political regimes. Perhaps the 
most famous geographer to take an avid interest in statistics was the Tuscan Attilio Zuccagni-Orlandini, who published an impressive chorography (a kind of encyclopaedia of geographical statistics) of Italy and its islands between 1835 and 1845. Zuccagni was appointed director of the new statistical bureau of the Grand Duchy of Tuscany in 1848 and attended several international congresses in that capacity. He also took part in the congress of 1867 in Florence, his native city, where he chaired the section on theory and technology.

In the Kingdom of the Two Sicilies in southern Italy, the French revolutionary tradition lived on in the central statistics department for Sicily founded in 1832. Its first director, Saverio Scrofani, had served as Napoleon's statistics and census official in Naples. ${ }^{10}$ Despite the efforts of Scrofani, his successors and the staff, the department failed to publish an orderly, long-term statistics series. The population and local elites were unhelpful and wary of greater intervention by the central state, especially in the form of higher taxes. Long after unification, Italian statisticians had difficulty overcoming these prejudices.

The congress in Florence revealed the problems inherent in the Europeanization of statistics like no other congress had before. Or, conveyed more optimistically, the Italian challenge was also the European challenge. Both Italy and Europe sought unity in diversity, a noble goal but - in the context of nineteenth-century political and economic reality - an illusion. Italian statisticians had taken part in the international congresses from the beginning, initially as representatives of the pre-unity states, but now they had the chance to express their national and European aspirations. Never before had the words 'Europe' and 'European' occurred so frequently in the congress proceedings. Without reservation Maestri wrote in the programme foreword that the international statistical congress had attained the status and importance of a European institution.. ${ }^{11}$

His friend and patron Cesare Correnti saw the statistical congresses as a harbinger of a European parliament. Correnti's patriotic ideas were interspersed with European references from early on. He was a student of Romagnosi and helped write his Annali universali di statistica. Between 1838 and 1844 he worked on the first Rivista europea, which was published in Milan. In the second volume of Annuario statistico italiano, published in 1864, he wrote about statistics as a 'pacifying science' in close consultation with Maestri. Citing Alexander von Humboldt, he called statistical numbers 'the final arbiters'. As Italy had been and was still being created by numbers, Europe would ultimately be shaped by statistics: 'a time will come when the European Areopagus resolves every problem through voting and numbers. ${ }^{12}$ In this pronouncement lay the beginnings of a European idea and a democratic ideal.

In the 1840s Correnti had an affinity for the ideas of Giuseppe Mazzini, an affinity that never completely left him, even when he became a member of parliament and Minister of Education of a united Italy and had no choice but to renounce the revolutionary aspect of the democratic philosophy. In statistics he saw a possibility of keeping some part of his democratic hopes alive: 'true statistics manifests itself, as it were, by way of a universal vote; it is everyone's 
confession to everyone; it is the discipline of democracy, and it is the reflexive and experimental consciousness of humanity.13

Under the Austrian regime Correnti had used statistics to avoid censorship and now statistics was giving him another opportunity to devise political projects without being called to account directly for his political convictions. His proposal for organising a municipal-level statistics, which he would promote at the congress in Florence, was another way of conveying his ideas about local autonomy, which clashed with the centralised administrative structure of the unified state.

For Correnti and Maestri, the international statistical congress presented an opportunity to actualise their interpretation of Romagnosi's and Gioia's ideas. Any state with a certain degree of freedom and openness should have an administrative statistics operation. Once a state had attained that level and acquired a statistical overview of the whole society, it would rise automatically to the next level, which entailed identifying the laws and patterns that governed human life. The next step was the highest level of science, 'the prophetic stage.' Attaining this level required international contact, and that was 'the moment of the international statistical congress. ${ }^{14}$ Though the congress movement was still in its infancy, international statistics was the only path to comparisons that would enable statisticians to distinguish general laws from coincidence and outliers. To the Italians, the European dimension of statistics verged on the universal.

\section{Preliminary work}

Maestri began his preparations in March 1865 by composing a letter to his fellow statisticians in Europe. He did not want the congress agenda to be determined solely by an Italian committee. His colleagues' replies began arriving in early 1866 , and some were published in the congress proceedings. In the meantime, the international commission established in Berlin to study the future of the congress had also discharged some preliminary work by post. It was clear, however, that the commission had not reached a consensus regarding how the congress could be given a more permanent character. The Dutchman Von Baumhauer, for example, feared that a permanent international commission of directors of statistical agencies would not survive. The idea of a supranational commission was a utopian one: no head of department could afford to take annual leave to go abroad and no government would bear the cost. Moreover, the commission would have no means of influencing or pressuring governments or private actors. ${ }^{15}$ It was difficult enough to find an organisational form that was congruent with the prevailing framework of international and scientific relations, but even simple, practical problems impeded progress in this area. The rapporteur of the international commission, Auguste Visschers of Belgium, was stranded on his way to Florence and lost his luggage. A trip from Brussels to Florence was no picnic in 1867. 
Since the congress was supposed to have taken place in 1866 (but had been postponed for a year due to the war), the programme was finished by spring of that year. There were to be eight sections: theory and technology of statistics, topography, agricultural statistics, municipal statistics, monetary statistics, moral and judicial statistics, military statistics and education. These topics were the cornerstones of 'modern' society, from the Italian perspective at least. Notably, trade and industry were not on the agenda, but municipalities were. We shall see that the selection of the latter had much to do with the political-administrative decisions that the right-leaning liberal elite had made in the early 1860s.

Various Italian and foreign rapporteurs shed light on these topics before the congress began. Correnti wrote a preparatory report on the issue of organising official statistics: how should a modern state structure its statistical research? This topic was incorporated into the theory and technology section. In keeping with Italian convention, Correnti referred to the debate between the realists and the idealists, initiated by Gioia and Romagnosi. The debate played out in the Kingdom of Naples, mainly among philosophers, but Correnti came to the conclusion that all that philosophising had distracted attention from the practical organisation of government statistics. And in his view organisation was the most pressing of political issues. The politics of unification was based on public opinion, and public opinion had to be fed with systematically collected and neatly arranged facts. Statistical inquiries needed to be fast, uniform, comprehensive and, above all, accurate. Like the justice system, statistics had to be fully autonomous and independent, because 'governing is a special way of evaluating or anticipating social data. ${ }^{16}$ What kind of institution would fit these requirements?

Foreign examples were difficult to merge into one format. In Europe, the autonomy of statistical inquiry was regulated differently from country to country. The threat of desegregation was palpable everywhere, which is why Correnti revived the congress's long-standing aspiration to institute a central council or commission for national statistics, which would act like a court ensuring that statistics did not become a bureaucratic plaything and was not used for piecemeal objectives.

Correnti also prepared the section on municipal statistics, a new topic for the international congress. The Paris congress of 1855 had taken a run at urban statistics, but Correnti's choice was, if anything, only tangentially related to that subject. He proposed to establish an international statistics that embraced 'the demographic and economic constitution of municipalities. ${ }^{17}$

Correnti's approach to municipal statistics cannot be understood without having some knowledge of the Italian state structure and the related debate. The proclamation of the Italian unified state in 1861 was a Bonapartist affair. In a blatant display of contradiction, every male inhabitant of the seized territories was permitted to vote in a referendum on annexation (the official results were without exception 99 per cent in favour and many a town hall has a stone or tablet commemorating the event), while the unified state adopted Piedmont's 
monarchical constitution of 1848 without parliamentary debate. Subsequently, the administrative laws of 1859, which had applied to Piedmont and Lombardy at the time, were introduced by decree. After an insipid parliamentary debate, Italy's public administration was finally codified in 1865, patterned almost entirely after the Kingdom of Sardinia.

The centralised unified state - which on paper resembled the Belgian state and the Thorbeckian structure in the Netherlands - was thus conceived. Free parliamentary, provincial and municipal elections were held, but the franchise was severely restricted (though it bears repeating that Italy was largely in step with the rest of Europe). The provinces were administered by government-appointed prefects, who reported to the interior minister. Mayors were also government appointees, but were elected by the municipal council first. Although parliament put up no resistance to the package of administrative laws presented to it, issues of centralisation and decentralisation were fiercely debated in newspapers, magazines and books before and after 1865. There was a large group of intellectuals who advocated greater autonomy and were gravely disappointed by the decisions of 1865 . Correnti was one of them, and his sentiments were unchanged in 1867.

Correnti's contribution to the municipal statistics section was a special document in which he attempted to integrate theories of political philosophy into the discourse on statistics. Before offering his thoughts on the function of statistics, he explained the nature of the modern municipality. Many statisticians considered the municipality a state in miniature. They studied the land, population, economy and crime at municipal level in the same way they would analyse those variables at a higher administrative and territorial level. According to Correnti, the crucial error was that this method concealed 'the essence of municipal life, its constituting principle, the relationship to other organisational forms. Political power was ultimately determined by the authorities that every municipality relinquished to the state in the public interest. Politics, therefore, began at the municipal level; the less power relinquished, the better the political system. If the municipalities retained their power, there was true autonomy; if the state intervened in every part of the municipal administration, there was a situation of tutelle, or tutelage. There were many intermediate and mixed forms in between these two extremes. In some cases, the status of a municipality vis-àvis the state was a historical condition, determined by economic circumstances or simply imposed by law.

By using the terms autonomy and tutelage, Correnti made it clear that he intended to keep the debate about Italy's administrative structure alive, although he made no mention of the centralising legislation recently adopted in his country. Correnti showed his hand only indirectly, by referring to administrative liberties that did not exist, or were not exercised, in Italy (such as cooperative partnerships between municipalities, differentiation of municipalities by size and location, appointments of official or semi-official physicians in rural areas). His argument appeared to have little to do with statistics, but he gave it an interesting twist. He demonstrated that statistical research could 
help ensure that a municipality was granted the most appropriate administrative status. All too often the autonomy conferred on a municipality historically or politically was incommensurate with its true economic, demographic and social potential. Statistics would prepare the way for diversity and flexibility.

The main variables of municipal statistics were, according to Correnti, the municipalities' political, administrative, financial and legal powers vis-à-vis higher levels of government and other organisations in society. He considered public health a special indicator. Statistical inquiry could play a helpful role in society by revealing the ratio of public health officials to population density. This information could then be used to determine whether more civil servants should be appointed or to ensure that more physicians set up practices in a certain area. Inter-municipal cooperation was an option worth considering because it could reduce the need for top-down interference. Correnti's examples show that he envisaged a structure of minimal state intervention at local level. The system in place in Italy in 1865 tended in the opposite direction, particularly in that it did not distinguish between large and small or urban and rural municipalities. Correnti wanted to show that statistics offered a sound scientific basis for making the centralised system more flexible.

How did the international community respond to his appeal? Probably only a minority understood the underlying message of administrative reform in its proper context. And those who did pick up the message were not inclined to burden the congress with it. Correnti's report was presented to all 128 participants of the fourth section. Most were Italians, since as usual the congress was dominated by the host country. Frenchman Maurice Block, who wrote about public administration issues as well as statistics, and understood the finer points of the proposal, was in charge of the discussion. During the first debate on 30 September, two distinct groups emerged: those, like Block, who wanted to begin by compiling a comprehensive questionnaire for the purpose of gathering municipal statistics and those who preferred to discuss the 'philosophical' side of municipal statistics.

Correnti was among the latter group but also realised that the congress had to produce a practical outcome. He defended himself against Block's ideas, which in his view were a throwback to 'the old method of analytical enumeration, which was very tedious and very difficult to complete. ${ }^{18}$ The majority of the section initially supported Block. To avoid offending Correnti, the section opted to have a subcommittee revise his proposal - by then a commonplace procedure for dealing with sensitive matters. In the end, the section decided to present a dual proposal to the plenary, incorporating both the 'philosophical' and practical elements of municipal statistics.

The Romanian delegate, Gregor Vulturesco, was the spokesman for the fourth section in the plenary meeting. Most of the discussion had taken place in Italian, which was illustrative of who was most interested in the subject. Not everyone understood Correnti, though. A departmental director from the Ministry of Agriculture, Industry and Trade, Raffaele Pareto, failed to see the project as anything but a general, national statistical inquiry on a smaller scale. This was 
precisely what Correnti wanted to avoid. He tried again to explain: 'Acquiring, collating and grouping data pertaining to various aspects of municipal life is different from writing a statistical monograph of a municipality. It is a function, a force, for which we want to find the statistical expression; it is not a form that can be photographed as it appears. ${ }^{19}$ Photography being a recent invention, the metaphor whetted their appetite for discussion but no new insights emerged. Ernst Engel exerted his influence and proposed adopting the fourth section's project unanimously, and so it was done.

Correnti's idea of municipal proportionality was mentioned in the preamble to the congress resolution, followed by a list of twenty questions on topography, public administration, finance and health. The health question was divided into fifteen sub-questions, which illustrates how important this issue was. Hardly any of the questions could be answered quantitatively..$^{20} \mathrm{~A}$ new kind of statistics was born, but could it possibly evolve into a European statistics?

\section{The will to reform}

The other topics addressed in the eight sections of the Florence congress expanded on resolutions adopted by earlier congresses. After Engel's example, Maestri had drawn up an overview of previous topics and resolutions in preparation for the congress. It was an impressive, methodical list, so well-ordered that it was immediately obvious that many resolutions had had no follow-up. However much the congress achieved, there was always more to be done.

With regard to language, the rules allowed the participants to choose between French and Italian. In practice, English and German were also spoken, and this was not particularly conducive to mutual understanding. The official opening was presided over by the Minister of Agriculture, Industry and Trade, who spoke briefly and turned over the floor to the statisticians without further ado. The rules of procedure were adopted quickly with little debate. The minister took the podium again on the second day. This time he delved a bit deeper into the significance of the congress for the young state of Italy. He emphasised the power of parliament, which in a short time had pushed through a range of reforms, whereby statistical research had played an important role. He intimated that the results of the parliamentary statistical inquiry were affected to a certain extent by the desired outcome. He urged the congress to find ways to keep the interests of popular representation and government statistics separate.

In an accident of circumstance, it fell to Vice-President Karl von Czoernig, an Austrian, to answer the minister. He spoke in Italian and tried to articulate the recent political changes in the Austrian monarchy. He extolled the virtues of the constitutional monarchy system, which availed itself of 'a national parliament, which being comprised of members from every social class, needs to acquire knowledge by means of statistical inquiry and to find in that knowledge the information and facts that are essential to making good laws. ${ }^{21}$ For someone who had long believed efficiency was more important than participation, these 
were decidedly remarkable words, which won him the support of the many Italians present.

The first section, theory and technology of statistics, addressed the organisation of the international congress and of government statistics in general, population statistics and nomenclature. Zuccagni-Orlandini, the éminence grise of Tuscan statistics, was named chairman of the section. Approximately 180 participants had registered for the section, including most of the foreign official representatives. One key issue was not presented to the section, namely the matter of reorganising the congress. The intended rapporteur, Visschers, was absent due to mishap, so Engel reported directly to the plenary meeting. In Berlin, the congress had decided to delegate responsibility for the issue to an international commission. In Florence, Engel spoke on behalf of the commission and urged great restraint: "Why should we tie the hands of the nations that will participate in future congresses by imposing on them fixed rules?' The congress in session was proof that every country was capable of organising an excellent gathering of statisticians in its own way. In the end, the Florence congress decided that 'the time was not come to codify the rules of the congress' and deferred the issue indefinitely. ${ }^{22}$

Correnti had written a preliminary report in which he emphatically reiterated the need for a single central statistics bureau and a single coordinating central commission. This was a perennial desire of the congress. On paper, Italy had been in compliance with this obligation since 1861. It had a statistics department at the Ministry of Agriculture, Industry and Trade, led by Maestri, and an advisory body, the giunta di statistica, chaired by Correnti. In practice, though, neither the statistics department nor the central commission operated flawlessly. The difficult relationship that existed between the various levels of government (municipal, provincial and national) was an obstacle to government statistics. Correnti used his report to the international congress primarily to re-introduce the organisational principles to his Italian colleagues. As usual, the foreign conferees showed intense interest in the subject, too, though it was unlikely that any of the delegates had sufficient political clout in their home countries to enforce the wishes of the international community.

At one of the meetings, Maestri explained again that in a representative system it was essential for statistics to serve the interests of both the legislative and executive powers. He endorsed a proposal put forward by Pietro Castiglioni, an official from the interior ministry, who like Maestri and Correnti was originally from Milan and had moved to Piedmont after 1848 due to his political convictions. The idea was that the central commission would consist of two sections: one was an advisory body made up of scientists and scholars and would be chaired by a member of parliament, and the other was to be comprised of ministerial officials and chaired by the director of the statistical bureau. The bureau would report directly to the prime minister. The proposal included specific guidelines regarding the activities to be carried out by each body.

Clearly, Maestri and Castiglioni were swept up in their own enthusiasm and 
consequently failed to see that the more nuanced and detailed their project was, the less viable it became. Experienced congress-goers like Adolphe Quetelet, who incidentally said very little in Florence, and Alfred Legoyt immediately put their finger on the problem: uniform institutions could not be imposed on states. ${ }^{23}$ This was a hard-won freedom that the nations of Europe enjoyed. At Engel's suggestion, the section decided it would suffice to inform the official representatives of Castiglioni's ideas and ask them to draw the matter to the attention of the organizing committee of the next congress.

Besides the organisation of the congress, there was one item that had been on the agenda of every congress since 1853: the census. In Brussels in 1853, the congress had spoken out in favour of counting actual population; in London in 1860, a proviso had been added calling for special lists to be drawn up of the legal population, as determined by the local registers. The discussion on this matter in Florence revived the recurring dilemma: should the congress pursue uniformity or accept national diversity in Europe? The Italian census of 1861 revealed that in some provinces the difference between actual and legal population ran into the tens of thousands. It was important to have an exact count of the legal population because many essential rights and obligations of the Italian citizenry (e.g. taxation, conscription, size of representative bodies) were based on the size of the population. That is why Giovanni Anziani, prior to annexation a member of staff at the statistical bureau of the Grand Duchy of Tuscany, proposed full implementation of the system of population registers (another topic addressed in 1853), so that lists of the total population in the various administrative units could be generated at any time.

The deliberations on this matter soon reached a precarious point. The Danish delegate, Christian G.N. David, clarified the distinction: counting the legal population served an administrative and financial purpose, and counting the actual population served a statistical purpose. The conclusion was obvious. The legal population count was contingent on the laws and customs of a particular country and could not, as Engel had correctly said, be deduced. No one dared to ask what categories could be determined by deduction. Count everything first, was Engel's straightforward motto. Only then was differentiation possible, as appropriate under national law. ${ }^{24}$

Legoyt pointed out another problematic dimension. Precisely because some unpopular civic duties were dependent on the population count, the information furnished by local authorities in France, for example, could not always be relied on. Mayors of small municipalities, of which France had many, were often inclined to spare their villagers and manipulated the statistics to do so. France was not alone: every country had its idiosyncrasies. Von Baumhauer, the Dutch representative, favoured counting only people with a permanent home, including those who were temporarily absent. The latter proviso was 'especially important in coastal countries. ${ }^{25}$ Friedrich Hardeck of Karlsruhe added that 'temporary' would have to be precisely defined since there were many types of temporary migration.

Engel tried to bring the discussion back to the main issue and warned: 'If 
we permit every country to implement their own system, we will forego the benefit of uniformity' - the basis of the congress. ${ }^{26}$ They decided to put to the plenary that the actual population should be counted first, that censuses should be conducted at the end of the year and that the 'manner and duration of abode of each individual' should be registered.

And then there was the matter of a standardised nomenclature for statistics. Maestri himself had written a preliminary report on this matter. The piece opened with an ominous statement: 'In order to present in international statistics comparisons and assessments of facts rationally, it is essential to verify that words have the same meaning everywhere they are used, that is, to ensure that a given concept is denoted by the same word in every country. ${ }^{27}$ This went to the very heart of diversity: was it human nature, history, the nation or something else that led to differences in the meanings of words?

Maestri suggested compiling a kind of pocket-sized dictionary of terms that could be important for statistical comparisons. But how to go about it? Maestri thought it would not be all that difficult. He selected several subjects (mortality, criminal law, reformatories and prisons, trade, shipping and finance - again, a typical list of nineteenth-century preoccupations), picked out one and explained the significance that Italian statistics and law conferred on aspects of the subject, and then asked whether country X had a similar concept. Sometimes the question was simple. The Italian budget distinguished between ordinary and extraordinary expenditures, based on the duration of the outlay. What was the criterion for this distinction in country $\mathrm{X}$ ?

In some cases, the question was preceded by a fairly extensive explanation. Italian statistics on reformatories and prisons did not address the causes of crime. No one knew, for example, whether idleness or ignorance led to a particular crime, which in turn resulted in imprisonment. So, it was necessary to ask whether country $\mathrm{X}$ had investigated such causes. Maestri was thinking of a country's economic and political situation, general culture, climate, race, epidemics, carnival season and the like. Could the conferees say whether the degree of public control was influential, what impact the intensity of passions had, or what the consequences were of moral decline? These questions were not directly related to a particular national framework but to a bourgeois moral standard, a worldview shared by the middle classes of most European countries.

The section members did not find the problem all that difficult. They mentioned initiatives that had already been launched. Quetelet referred to an international population statistical survey that he and Xavier Heuschling had published in 1865, based on a resolution adopted by the London congress. They had simply translated all the relevant terms into French. He was convinced that it was possible to do the same for other subjects, too. The section wrote a draft resolution proposing that the required definitions be included in each statistical publication. The true extent of the problem became clear when the discussion turned to life insurance and causes of death. Differences in how causes of death were defined led to disparate counts, and those counts led in turn to differences 
in premiums and payouts. This had an impact on the liquidity of life insurance companies. The subject cried out for further inquiry.

The plenary meeting did not add much to the debate on the themes of the first section. Castiglioni readily admitted that the reorganisation of government statistics had an administrative and political side as well as a scientific one. Yet, given the recent political upheaval in Europe, the inception of the unified Italian state and the establishment of the international congress itself, by comparison a 'very innocent revolution, a revolution in the structure of official statistics' should fall within the realm of possibility. Castiglioni supported Correnti's proposal for an autonomous government statistics configuration, consisting of a central commission and a central bureau. This would institutionally entrench the basic principles of the liberal state: freedom and authority. And with that, the matter was closed until the next congress.

Ernst Engel took the floor to introduce the debate on the census. His speech was technical, apolitical and brief. In his opinion, a census was more than a count of a country's inhabitants. People were asked about their personal circumstances, and their position in the family, the community, the state, the church and society. In other words, a census was an essential building block of demography. The biggest impediment to accuracy was that people moved around for various reasons - seasonal work, military service and illness. Engel proposed counting the actual population, and asking everyone whether they were born in the municipality conducting the count. If not, they would be asked to indicate how long they had been living in the municipality. The worst that could happen was that an inhabitant might 'appear' to be deceased if he was not registered on any census list because he was outside the territory at the time of the count. It was preferable to hold a census in the winter, at the end of the year, since most people stayed 'at home' then. Incidentally, a question about the degree of consanguinity between fathers and mothers was added. Some people could not resist the temptation to ask for more information than was strictly necessary, although admittedly consanguinous relationships had been a legal issue for many centuries and had also entered the debates on public health.

The addition of extraneous questions annoyed Legoyt, the dogmatic French representative. William Farr shared his disapproval, while Engel took a pragmatic approach: governments were not required to adopt every proposal the congress made. This statement, verging on radical, unequivocally exposed the weakness of the congress. His goal was to preserve harmony among the conferees at any cost. Legoyt insisted that his objection be registered in an official report, at the very least. In the end, everyone was satisfied, but no real progress was made on the census.

The fifth section addressed the matter of monetary circulation, a problem that Italy had dealt with in 1862 by making the Piedmontese lira the national currency. In theory, though, the problem required a supranational solution. The underlying issue was the desire to have all governments introduce the decimal system and a standard European system of weights, measures and 
coinage. The Florence congress, like its predecessors, advocated this change. That the statistical congress willingly took on this set of problems demonstrates its overconfidence, despite many setbacks and failed resolutions. France, Italy, Switzerland and Belgium had concluded a monetary agreement in 1865 and international commissions had met in Paris to discuss this issue in 1867, prior to the congress. The debate in Florence was a bit too technical for the statisticians. The rapporteur of the fifth section, Pascal Duprat (a Frenchman in exile for his republican sympathies), insinuated that his section had arrived at a unanimous proposal.

During the plenary session, however, it turned out that Leone Levi had his own agenda and intended to urge the congress to display greater boldness in the pursuit of monetary union. Levi had been a regular participant since the first statistical congress, and was on the council of the Statistical Society of London. He was born in Ancona but moved to Britain in 1844 and became a naturalised British citizen soon after. Trade law was one of his areas of expertise and he periodically issued a statistical summary of the Parliamentary Papers. At the very least, Levi wanted to put together an international commission to focus exclusively on the monetary issue. Duprat reiterated with emphasis that the international statistical congress was rooted in the pursuit of science and had no political power to speak of. Louis Wolowski believed that the sole purpose of statistical inquiry was to gather data, in this case regarding the production and circulation of precious metals and money. The congress decided to maintain its course and voted in favour of the fifth section's proposal, which was consistent with Wolowski's view.

\section{Les misérables}

The sixth section concerned itself with the loaded dual topic of moral and judicial statistics. Justice in the nineteenth century was not infrequently a deeply moral issue, so the combination was not surprising. Two preliminary reports had been drafted: one by Angelo Messedaglia, a statistician and expert on public administration, on the classification of offences, and another by Pietro Maestri, whose topic, 'Les misérables', had been on the agenda back in 1853 but due to its political character had not been addressed as a separate issue since then.

Maestri thought poverty should be studied in two ways. The first approach involved investigating the cause of this 'anomaly', determining whether the cause was permanent or temporary and identifying the legal or moral changes that would need to be made. The second approach was a study of the phenomenon itself. With regard to the latter, Maestri had noticed that the indigent formed a heterogeneous group that included convicts, foundlings and prostitutes, to name but a few: 'Each of these classes of individuals has a special significance but together they form a broad category of suspect cases; dangerous to others and to themselves, and necessarily subject to surveillance..${ }^{28}$ Statistical studies of poverty could examine the natural, civil, moral and economic situations of 
the needy and how they were dealt with (in charitable institutions or prisons). But it was also necessary to seek a remedy for the problem. In Maestri's view, there was an overemphasis on mitigating poverty and too little concern for prevention. There was barely any coordination between charitable institutions. Maestri thought that the congress should advocate the establishment of a general committee for the protection of the underprivileged. The committee's task would be to coordinate public and private efforts to reduce poverty and recommend reforms. Once again the congress found itself confronted by an issue that appeared to be beyond the scope of statistics.

The fact that it was Maestri, the hard-working organiser of the Florence congress, who made this proposal underlined the importance of the issue. Soon after Italy's unification, the government had commissioned a statistical inquiry on poverty, which was in fact more of an investigation into the state (financial and otherwise) of the institutions than a study of the poor. As director of the statistics department, Maestri was responsible for publishing the research, a task he was still working on at the time of the congress.

Poverty was one of the most pressing social issues of the day and thinking about it dovetailed neatly with the statisticians' penchant for classification. In the nineteenth century, countless attempts were made to subdivide the indigent into categories. The fundamental distinctions were between the genuinely unfortunate and the idle, between the deserving and the undeserving poor. This explains Maestri's distinction between temporary and permanent paupers. While he engaged in the debate about the form and usefulness of charity, Quetelet's ideas could be heard echoing in the background. By analogy to the scientific approach to astronomical phenomena, Quetelet was a fierce advocate of tracing the causes of social phenomena. The goal was to eradicate 'temporary' causes and with them social evils. The same could be applied to poverty and pauperism. In that sense, the proposal to establish an international committee for the protection of the underprivileged was an extension of statistical inquiry. Reform-minded intellectuals and civil servants, who were presented in large numbers, found the proposal acceptable in all respects.

\section{Statistics of culture}

The statistics of art schools, archives, libraries and museums was an entirely new topic that none of the previous congresses had addressed. A statistical analysis of this kind might seem unusual to us, but it should be clear to the reader by now that in the nineteenth century people attempted to count and categorise just about everything. Moreover, the statistics of culture had everything to do with Romagnosi's idea of 'incivilimento', or at any rate what later generations made of it. The organisers even ventured to suggest that people would not only be interested in collecting data about cultural institutions but would also seek to make organisational improvements. Another reason for Maestri and his colleagues to put this item on the agenda was Florence's mission to uphold its 
reputation as a city of culture.

Maestri opened the discussion with a piece about art education. Again, moral arguments abounded. Maestri proclaimed: 'Art is the product of the common culture. ${ }^{29}$ Schools were needed not only to make artists aware of beauty and artistic traditions, but also to imbue the working class with taste. The objectives of statistical inquiry ranged from identifying schools to determining what styles they taught, what prizes were awarded and how many students they had. The same kind of broad interest, frequently more qualitative than quantitative, emerged when the proposal regarding the statistics of archives and libraries was put forward. The moral and cultural influence of these institutions was a topic of great interest, and statistics could reveal those influences and enhance them. Attention was also drawn to such matters as bibliography and the training of librarians. The science of bibliography was basically one of classification, a task made for statisticians. The preliminary report drafted by Tommaso Gar, who had recently been appointed director of Venice's state archives, cleverly appealed to this thirst for order: 'The life and soul of all libraries is rational order, the methodical classification of the works they contain. ${ }^{30}$ Every statistician present would have taken this to heart.

Most members of the eighth section, which was responsible for these matters, were Italian. Despite the overlaps in the area of classification, the relationship between statistics and cultural institutions was not clear to everyone, which occasionally led to bizarre discussions. The disagreement about opening hours typified the futilities that preoccupied the conferees. The risk of digression was just as high during the plenary debates. The delegate from Padua, Andrea Cittadella Vigodarzere, delivered an impassioned speech about the decline of Italian painting. If it was possible to study the causes of poverty, he argued, it was also possible to discover why the art of painting was in decline. This must have boggled the minds of many listeners. And the report on the statistics of museums was yet to come. Achille Gennarelli, archaeologist and palaeographer, asked the question everyone had been avoiding: 'Is a statistics of the whole world possible?' ${ }^{31} \mathrm{He}$ assumed it was. But he also said that statistics of the present had little significance without knowledge of the past. Ethnographic statistics, which had been discussed extensively in Vienna, needed to be viewed from a historical perspective to be fully understood. Museums were an ideal source of historical knowledge, especially if they were acquainted with each others' collections. The task of the statistician was to produce questionnaires that would yield a clear survey and accessible catalogues.

The Italians appeared to be oblivious to the fact that their infatuation with these topics was causing the cohesion of the congress to erode further. Those who regularly attended the statistical congresses remained reticent during these discussions, preferring not to engage in a debate about the domain of statistics. Obviously, there was a great deal of uncertainty about where the boundaries lay. There was also a lack of consensus on statistical methods. One minute, statisticians were calling for the theory of probabilities to be given greater precedence, and the next they were satisfied with a questionnaire that would yield nothing 
more than a museum catalogue. The only thing everyone agreed on (in silent consensus) was that statistics had the potential to address every issue and was an essential first step towards progress.

The final plenary was devoted to discussing the location of the next congress. On behalf of the Netherlands, Von Baumhauer had already expressed an interest in organising the event. His offer was received with gratitude, but he had competition. William Farr made a case for Russia, the only great power that had not had a turn at hosting the congress. Farr gave two reasons: first, Russia was a vast country and an enormous producer in many industries, and was therefore rich in statistical potential; second, Russia had recently implemented major political and social reforms. Farr stressed that by abolishing serfdom, the tsar had made a giant step forward on the road to modernisation, a step that should be acknowledged by the congress. If Russia was not in a position to organise the next congress, the alternatives were, according to Farr, Sweden, Denmark, the Netherlands and Switzerland.

Von Baumhauer defended the Netherlands' candidacy in German. With no discernable hesitation, he praised the land of Rembrandt, a seafaring nation liberated by means of the Eighty Years' War and since then the standard-bearer for a free and enlightened Europe. The Dutch economics and statistics association, the Vereniging voor de Staathuishoudkunde en Statistiek (1849), had enough capable members to put an organising committee together. He added that the location and climate of The Hague made it an excellent venue.

The French representative Wolowski supported the Netherlands' bid with a formal argument (one does not reject an invitation) and a substantive argument: '... everyone knows that Holland gave the world its first example of what can be accomplished by persevering in the love of freedom and making the sacrifices that love demands. ${ }^{32}$ The discussion continued in a similar vein. Engel sang the praises of the private statistics associations in Switzerland: official statistics was, after all, ultimately reliant on the cooperation of the citizenry. The Swiss representative, Giovan Battista Pioda, happily continued along these lines and explicitly confirmed his country's candidacy. Von Baumhauer could not refrain from responding that the Netherlands was no less free than Switzerland, stating 'our King rules over a free nation, he does not rule over her as if she were a slave; and we love our King as one loves a father, not as one loves a master. ${ }^{33}$

This was the kind of language statisticians used when they abandoned the domain of numbers. The platitudes betrayed their preoccupation with the threats to, and refuges of, bourgeois civilisation. The congress in Florence demonstrated that dual concern like no other, with its debates on the statistics of migration flows, crime and poverty on the one hand and research into charitable institutions, land registries or cadastres (protection of property!), uniform weights and measures, art and culture on the other.

The proceedings concluded with the usual words of praise for the organisers, and Maestri in particular. It is doubtful whether the congress was considered a success afterwards. It was a gathering that had coupled reformist thinking 
with lacklustre compromises and European aspirations with national interests. Concrete results were few and far between. It was clearer than ever that no resolution would ever have a direct impact on statistical practice, and the official representatives voiced this observation with increasing frequency.

The European ambitions of some of the Italian delegates were a relic of early liberal nationalism but were out of touch with the realism that began to dictate international relations after 1860. Italy's vision of Europe was very different from that of other countries. In its enthusiasm, Italy had reverted to an obsolete ideology, as if it could shore up its own legitimacy by making a bold appeal for a European future. Most of Europe's governments had long considered that notion passé.

\section{Notes}

1 U. Pesci, Firenze Capitale (1865-1870) (Florence 1904), p. 387.

2 P. Maestri, Annuario economico e politico dell'Italia per l'anno 1852 (Turin 1852) and Id., Annuario economico-statistico dell'Italia per l'anno 1853 (Turin 1853).

3 Maestri, Annuario economico e statistico dell'Italia per l'anno 1853, V.

4 Cited in F. Sofia, Una scienza per l'amministrazione. Statistica e pubblici apparati tra età rivoluzionaria e restaurazione (Rome 1988), p. 320.

5 M. Gioia, Filosofia della statistica (Milan 1826), III.

6 Ibid., XI.

7 S. Patriarca, Numbers and Nationhood. Writing Statistics in Nineteenth-Century Italy (Cambridge 1996), p. 41.

8 Compte-rendu des travaux de la sixième session du Congrès International de Statistique réunie à Florence les 30 Septembre, 1, 2, 3, 4 et 5 Octobre 1867 (Florence 1868), p. 349

9 U. Levra, 'La "statistica morale" del Regno di Sardegna tra la Restaurazione e gli anni Trenta: da Napoleone a Carlo Alberto', Clio 28 (1992), 353-378.

10 For an account of pre-unitary statistics, see Patriarca, Numbers and Nationhood, and G. Favero, Le misure del Regno. Direzione di statistica e municipi nell'Italia liberale (Padova 2001).

11 Compte-rendu des travaux de la sixième session, 8.

12 Annuario statistico italiano 2 (1864), XXIII.

13 Ibid., XXV.

14 Ibid., XXVII-XXVIII.

15 Compte-rendu des travaux de la sixième session, p. 37.

16 Ibid., p. 50.

17 C. Correnti, 'Statistique comunale: constitution démographique et économique des communes', Compte-rendu des travaux de la sixième session, pp. 111-124. His argument is also discussed, albeit with a different emphasis, by Patriarca, Numbers and Nationhood, pp. 210-232, and Favero, Le misure del Regno, pp. 97-113.

18 Compte-rendu, p. 234.

19 Ibid., p. 381.

20 Ibid., pp. 483-484.

21 Ibid., p. 349.

22 Ibid., p. 393.

23 Ibid., p. 201.

24 Ibid., pp. 204-205.

25 Ibid., p. 206.

26 Ibid., p. 207. 
27 Ibid., p. 58.

28 Ibid., p. 131.

29 Ibid., p. 145.

30 Ibid., p. 153.

31 Ibid., p. 446.

32 Ibid., p. 461.

33 Ibid., p. 463. 